PLEASE NOTE! THIS IS SELF-ARCHIVED VERSION OF THE ORIGINAL ARTICLE

To cite this Article: S. Juvonen (2018) The answer is project-studies! Learning integration with research and development projects. INTED2018 Proceedings, pp. 2658-2663.

doi: $10.21125 /$ inted.2018.0505 


\title{
THE ANSWER IS PROJECT-STUDIES! LEARNING INTEGRATION WITH RESEARCH AND DEVELOPMENT PROJECTS
}

\author{
Conference Paper · March 2018
}

DOI: $10.21125 /$ inted.2018.0505

\section{CITATIONS}

0

1 author:

\section{Sanna Juvonen}

Laurea Universities of Applied Sciences

5 PUBLICATIONS 1 CITATION

SEE PROFILE
READS

7

Some of the authors of this publication are also working on these related projects: 


\title{
THE ANSWER IS PROJECT-STUDIES! LEARNING INTEGRATION WITH RESEARCH AND DEVELOPMENT PROJECTS
}

\author{
Sanna Juvonen \\ Laurea University of Applied Sciences (FINLAND)
}

\begin{abstract}
Research and development (R\&D) projects offer a unique study platform for students in higher education. At their best, higher education studies can be implemented in projects in a way that combines practice-oriented tasks and scientific approaches to provide students real working life experiences. This article introduces student-centred approaches, especially the pedagogical action model, Learning by Developing (LbD), in project's learning environments in higher education. The pedagogical action model integrates learning in higher education with R\&D projects in collaboration with teachers, project members and work-life representatives. In addition, it highlights students as active learners who develop skills in authentic projects and apply their knowledge in logical, intuitive and creative ways. The beginning of this article presents background perspectives on the integration of learning and projects and pragmatic frameworks behind project studies. It continues to view few similar pedagogical practices in R\&D projects for higher education before describing the LbD-action model. Furthermore, this article introduces case example of experiences in learning integration with $R \& D$ projects. It includes a reflection on the challenges and possibilities of combining R\&D projects with higher education.
\end{abstract}

Keywords: higher education, student-centred learning, Learning by Developing (LbD) -action model, R\&D projects.

\section{PRAGMATIC FRAMEWORK BEHIND PROJECTS}

This paper focuses on integrating learning with R\&D projects. Briefly, this paper describes how learning can be combined with R\&D projects, which aim is to research and develop for certain challenges. When an R\&D project is coordinated by a higher education institution, such as the Universities of Applied Sciences (UAS), learning integration is a natural part of the project's tasks. Projects offer unique and authentic learning environments where students can implement a project's tasks by combining learning tasks with a project's need. Learning tasks need to be planned by professionals with strong pedagogical skills to guarantee that they correspond to learning objectives and align with the students' education level. Finnish UAS have strong expertise in R\&D. There is a demand for UAS to create applied R\&D work in its region in addition to offering learning possibilities for undergraduate and graduate-level students. Pirinen (2015) [1] described R\&D projects as an integrative way of learning where students learn in a workplace, school and R\&D community while their projects produce new competences and activities.

According to the Applied Sciences Universities Act (932/2014), the duty of the UAS (Section 4) is to provide the framework of research in working life and to support the student's professional growth. In addition, it is the duty of the UAS to carry out research, development and innovation activities that support education, promote working life, regional development, reform the region's business structure and carry out artistic activities. In pursuing these duties, the UAS must promote lifelong learning. [2].

The integration of education with the R\&D activities has been a challenge for the UAS to ensure that both education and R\&D activities are strengthened. This article addresses the goals, challenges and possibilities of integrating education and R\&D projects.

Collaboration between education and R\&D projects requires proper planning. R\&D projects offer numerous possibilities for higher education students: students become active learners with exposure to multiple disciplines and professions in their curriculum. Their studies incorporate projects and working life opportunities, and students participate innovative learning environments where theory and practice are integrated. [2].

Integrating learning with research development projects in higher education aligns with the Applied Sciences Universities Act. Learning in projects is student-centred where learning tasks are based on ongoing R\&D projects planned by pedagogy. Additionally, learning tasks are planned for students' 
degree programmes so project studies will be accredited to a student's degree to compensate for other compulsory studies.

According to Taatila and Raij (2012) [3], the pragmatic framework fits with the pedagogic philosophy at the UAS where learning creates new competencies for contemporary working life. The aim of the pragmatic framework is to translate useful knowledge of real-life problems to develop students for the expectations and needs of their regions. Ardalan (2008) [4] suggested pragmatic learning is vocationally directed, so every learning situation should increase practical competence [4]. According to the pragmatic learning philosophy, a teacher is a learning guide and mentor for students who create their own reality. Pragmatism makes students gather their own situational facts and create their own reality [5]. This is possible for Master degree students in Finnish UAS, as they have already working experience when they are able to start their master studies. As such, the students in this study were already experts in their field and pragmatic learning philosophy supports and motivates their learning. Further, this article introduces case examples of learning integration with R\&D projects and includes experiences gathered from students studying master studies. Projects are an excellent learning environment for graduate students.

As earlier mentioned, at the UAS, students typically have at least three years' working experience after their undergraduate degree before applying for their master's degree. Furthermore, Ardalan (2008) [4] pointed out that pragmatic universities provide students with real tasks in changing situations and thus, those situations are learning experiences [4]. The aim of the Finnish UAS is a pragmatic-oriented educational system based on the requirements of working life and society with its practical, ever-changing problems [3].

\section{STUDENT-CENTRED PEDAGOGICAL APPROACHES}

This article addresses student-centred pedagogical approaches, which are often utilized to integrate projects and education. Student-centred pedagogical approaches highlight students as active learners with opportunities to develop skills in authentic projects so they can apply their knowledge and abilities in logical, intuitive and creative ways. The article views pedagogical approaches: Problem-Based Learning and Learning by Developing.

The constructivist learning approach, the foundation of problem-based-learning, considers learning as an active social and cognitive process, where learners build their picture of the world by interpreting new information (gained from participating in social activities with each other) in relation to already existing knowledge. Constructivist pedagogy highlights a learner's active role and the importance of social interaction in learning. [6]. Based on constructivism, learning is a change in an individual's perception of a specific phenomenon [7]. The sociocultural perspective in constructivism describes joint construction of meaning through community activity and provides the student with the traditions, tools, symbols, artefacts and language of the learning community. Constructivism view how students determine meaning from content knowledge interaction [8] whereas pragmatic learning theory considers learning as the foundation of habits [9].

Pragmatically oriented LbD-action model is similar in many ways to constructionist-based learning theory like the problem-based learning model that situates learning in complex problem-solving contexts and offers students opportunities to consider how the facts they study relate to specific problems. Problem-based learning increases motivation for learning, since students are more motivated when they value what they are learning [10]. Students are also more motivated when they believe the outcome of learning is under their control [11] Problem-based curricula guides students' learning experiences through solving complex, real-world problems. The pedagogical approach was designed with several important goals for students: construct an extensive and flexible knowledge base, develop effective problem-solving skills, develop self-directed skills, become effective collaborators and become motivated to learn [12].

The LbD-action model was based on projects that were created together with working life representatives, lecturers, students, workplace experts and end users. In the LbD-action model, the project creates the learning environment [13]. Other specialties of the LbD-action model are outlined as follows [13]:

1 R\&D projects are a unique, working life-oriented starting point for a study.

2 Action models based on collaboration with teachers, students, working life representatives and end users result in knowledge and competency integration. 
3 The result of sharing and interpreting observations is the abductive formation of a hypothesis, verified through deductive and inductive reasoning.

4 The R\&D projects are learning environments that involve knowledge in practice and new competencies produced through and for work.

$5 \mathrm{LbD}$ increases the collaboration between different experts.

6 LbD offers a platform for creating students' competency.

7 The results in LbD are new competencies in new habits, action models and new innovations.

8 Learning happens when project participants achieve new ways of action and new habits for a changing world.

Earlier research findings concerning learning in a professional context (Raij, 2000) had led to the following identification knowledge types: 1) knowledge in theories and models, 2) knowledge embedded in skills and abilities, 3) moral knowledge, and 4) experiential knowledge corresponding to the components of professional competence as knowing, understanding, doing and situation management as an integrated whole. [14]

This article focuses on the Finnish pedagogical action model, LbD, which was developed to integrate education and R\&D projects in higher education. The aim of the UAS in Finland is to integrate regional development, pedagogy and R\&D into one frame of operations. According to Taatila (2014) [15], the learning approach is student-centric, offering authentic R\&D work in projects. Students get the chance to research relevant topics, use their research to come up with creative solutions and get practical experience putting their plans into action. In the pragmatic approach, the student must be placed within situations to personally experience problems. Raij (2014) [16] explained that R\&D projects offer new questions to study by presenting new situations where earlier ways of action were insufficient in a changing social world.

In a pragmatic university, like UAS in Finland, research is a goal-oriented task which aim is to solve problems by producing new knowledge. The aim of research is to support development activities. [3] Kallioinen (2014) pointed out [17] that crucial LbD factors included subject-specific competence, a research-oriented approach, interaction skills, the ability to engage with colleagues, students and partners dialogically and having pedagogical competence. Qualified teachers foster students' motivation and participation. The learning process, guidance, peer-reflection, professional and human growth and a research-oriented, developmental approach to work are priorities in LbD. LbD supports the development of independent thought, an experiential study atmosphere, and responsibility.

As earlier described, the LbD-action model is similar to other student-centred pedagogical approaches, such as the problem-based learning approach reviewed in this study. According to Raij (2011), problem-based learning focuses on learning outcomes and the curriculum, whereas LbD has a wider approach toward curricula and a stronger focus on R\&D. In the LbD-action model, studentcenteredness and equality between lecturers and students are preeminent [18]. Authenticity, R\&D perspectives and working life-orientation are the main values in $\mathrm{LbD}$ and the main reasons why pragmatically oriented action models were chosen as the learning approach in this study. It creates a learning environment for studying what kind of learning takes place in projects.

\section{CASE-EXAMPLE OF INTEGRATION}

Article addresses learning integration in R\&D projects. Workplace orientations and professional opportunities help students, teachers, working life experts and end users, but research on R\&D project-learning is still lacking at the Universities of Applied Sciences who report from their studies to the Ministry of Education and Culture. It has been noticed that study point completed in R\&D projects is minor compared to the amount of R\&D projects in UAS. This article introduces case examples of integration processes where ten students conducted qualitative methods-based research. This research is not yet completed, but initial insights are introduced next.

Ten students who participated in project studies were interviewed and observed, at the beginning and at the end of academic year, in 2017. Students were in the beginning of their Master degree studies. They had completed their bachelor degree studies and wanted to continue studying but decided to study in R\&D projects. It seemed to be that student who decided to study through projects were motivated to study in ways beyond traditional study methods. The first insights regarded learning processes, experiments and study possibilities of students studying in R\&D projects. 
The experiments of this presentation were collected from Laurea University of Applied Sciences in Finland where a new study programme, Open University of Applied Sciences, has started. This study programme provides graduate students (with at least two years of working experience) the opportunity to pursue their master's degrees through R\&D projects. According to Ojasalo, Juvonen, Kaartti and Haapaniemi (2017), this study path systematically integrates higher education studies with R\&D projects. Each of the courses were implemented in ongoing and externally funded projects. Instructors and project managers with pedagogical backgrounds developed study units for R\&D projects where tasks corresponded to graduate level learning objectives. [19]

Projects offered learning environments for the students to learn to recognize areas of development in projects students participated. Some of the students learned to create new solutions while working on their study tasks. Scientific approaches related to all the study tasks. While this was easy for some of students, others struggled with research articles. Students' roles in the projects were comparable to their project members and some students used this opportunity to network even though some students did not take advantage this opportunity since equality within the project group did not matter to them. Each of the students needed guidance and support. If they studied independently, their results may not have met graduate-level requirements. Students learned the value of organizing regular study meetings where they could share their experiences and asked for advice from peers, teachers or project managers.

\subsection{Challenges in project studies}

Students studied in externally funded projects, which were not created with pedagogical aims in mind, despite their associations with higher education institutions as partners or project coordinators. However, externally funded projects offered unique study possibilities for the students. Projects focused on new development areas and offered students important knowledge for developing their professional skills. Still, the learning environments were challenging. For example, project schedules did not always easily fit into semesters and created uncertainty for students. Those who has worked in projects before R\&D -project studies started, knew that project plans continuously change and therefore project tasks might be difficult to schedule. This created challenges for their personal study schedules, especially since most were full-time workers.

In a real-life project, project tasks change and are rarely reusable from year to another year, as opposed to the traditional study units. This caused challenges to the students when they could not complete earlier study tasks. Some of the students would have needed this perspective, to take the model from earlies study tasks. Furthermore, few students hoped to get clear timetables for their studies, but this was not always possible. Studying through projects was not the easiest way of studying for students who were more motivated and interested in study points rather than learning and new experiences. Misunderstandings between students and project staff, misleading hopes and lack of communication were the most common challenges. Further, external motivation did not foster learning experiences. Students with unclear hopes for their future working life, as well as little work experience, negatively affected their learning and studies.

\subsection{Advantages of project studies}

Students were offered real working life experiences by participating in R\&D projects during their studies [19]. Integrated learning motivated students to pursue real life projects. End users and project consortiums were interested in implementing students' tasks and study tasks concerned unique and new issues. Students had the opportunity to develop their skills and knowledge while preparing for tasks which will hopefully be implemented in real life. This was the best way to integrate studies and LbD-action models.

Immonen-Orpana (2009) showed how students, studying through LbD-action models, could construct their own individual and shared concept maps without a teacher's guidance. In her studies, students created new concepts and new kinds of links between concepts. [20] This also occurred in this study. The best students created new concepts in response to project requirements. Studying remotely and working required connections with study groups, which were usually project teams with small groups of students. The students who made these connections were more active and their study results were good.

Motivated students wanted to study in projects to gain new information they could apply in their own working life. Project studies were interested in students who were not only studying toward a degree, but willing to learn something that could be used in their profession. It seemed that students with 
strong working experiences succeed most in the project studies and benefitted more from the experience. They got new contacts from their project consortium. Those students understood their projects' backgrounds. They already had extensive knowledge, which helped them to learn new things. In addition to specific project tasks, students could view the whole project with its partner organization and project management. Those students benefited from the LbD-action model and shared their experiences, reflections and conceptions. Raij (2011) highlighted that projects were a means for collaboration between working life experts, clients and lecturers to guide and competently evaluate students [18].

Based on the results of this article, it is important and fruitful to continue the work with learning integration with R\&D -projects. Especially, learning is interesting process to take into the consideration when looking at effectiveness of $\mathrm{LbD}$-action model, which has created diverse learning environment for higher education institution. Now is the time to study what kind of learning is happening in integration with learning and R\&D -projects when applying LbD -action model. The study related to the Master degree students' learning continues. At the same time, the development work related to the LbD -action model continues for example by creating model more transparent without forgetting student guidance and competence evaluation. Currently Universities of Applied Sciences are figuring out best learning solutions and learning environments to respond to the requirements for the knowledge in changing society. It will be seen, whether the answer is in projectstudies in the future!

\section{REFERENCES}

[1] R. Pirinen, Functional Frames of Learning by Research and Development, Journal of Modern Education Review, 2015, Volume 5, No. 6, pp. 540-563. Retrieved from http://www.academicstar.us/UploadFile/Picture/2015-11/20151117211014834.pdf

[2] Arene, Innovation, development and research - All letters in use in the RDI activities of Universities of Applied Sciences 2017: Retrieved from http://arene.fi/sites/default/files/PDF/2017/TKIRAKE/Innovation\%2C\%20development\%20and\%20research_Web.pdf)

[3] V. Taatila \& Raij, K. Philosophical review of Pragmatism as a Basis for Learning by Developing Pedagogy. Educational philosophy and theory, Volume 44 (8), 2012.

[4] [K. Ardalan, The Philosophical Foundation of the Lecture-Versus-Case Controversy. Its implications for course goals, objectives and contents, International Journal of Social Economics, 35:1/2, pp. 15-34.2008.

[5] V. Taatila \& K. Raij, Philosophical Review of Pragmatism as a Basis for Learning by Developing Pedagogy, Educational Philosophy and Theory,Vol. 44, No. 8, 2012 Retrieved from: http://web.a.ebscohost.com.nelli.laurea.fi/ehost/pdfviewer/pdfviewer?vid=1\&sid=d251ccbace82-48fe-a05a-7b24ed857ecc\%40sessionmgr4009

[6] P. Tynjälä, Konstruktivistinen oppimiskäsitys ja asiantuntijuuden edellytysten rakentaminen koulutuksessa, teoksessa Oppiminen ja asiantuntijuus (toim. A. Eteläpelto \& P. Tynjälä), WOSY, 2005.

[7] A. Järvinen, Reflektiivisen ajattelun kehittyminen opettajankoulutuksen aikana. Jyväskylän yliopisto, Kasvatustieteiden tutkimuksen julkaisusarja A. Tutkimuksia 35, 1990

[8] S. Papert, Paper on Piaget, Time Magazine, 1999, Retrieved from: http://www.papert.org/articles/Papertonpiaget.html

[9] O. Kivinen \& P. Ristelä, From Constructivism to a Pragmatist Conception of Learning, Oxford review of education, 29, (3), 363-375. 2003

[10] M. Ferrari \& R. Mahalingham, Personal cognitive development and its implications for teaching and learning. Educ. Psychol. 33: 35-44.1998.

[11] A. Bandura, Self-Efficacy: The Exercise of Control, Freeman, New York 1997.

[12] H. Barrows \& A. C. Kelson, Problem-Based Learning in Secondary Education and the ProblemBased Learning Institute (Monograph 1), Problem-Based Learning Institute, Springfield, 1995.

[13] K. Raij, Learning by Developing, Laurea Publications A 58, Edita Prima Oy, 2007. 
[14] K. Raij, Toward A Profession. Clinical learning in a hospital environment as described by student nurses. Research Report 166. Helsinki University: Department of Education. 2000.

[15] V. Taatila, Some Experience-Based Considerations on the LbD action Model In Learning by Developing Action ModeL (edit. K. Raij), Laurea Publications 36, Grano Oy. 2014

[16] K. Raij, Learning by Developing in Higher Education, In Learning by Developing Action ModeL (edit. K. Raij), Laurea Publications 36, Grano Oy. 2014

[17] O. Kallioinen, Producting Mode 2 Knowledge in the LbD Action Model Processes, In Learning by Developing Action ModeL (edit. K. Raij), Laurea Publications 36, Grano Oy. 2014

[18] Learning by Developing LbD guide, K. Raij \& S. Niinistö-Sivuranta (eds.) Laurea University of Applied Sciences, 2011. Retrieved from: https://www.laurea.fi/en/document/Documents/LbD_Guide_04102011_ENG.pdf

[19] K. Ojasalo, S. Juvonen, V. Kaartti \& H. Haapaniemi, New approach and tools for systematic integration of higher education with research and development projects. Proceedings of INTED2017 Conference, 6th-8th March 2017.

[20] P. Immonen-Orpana, Onnistuneen ikääntymisen ymmärrystä rakentamassa Fysioterapeuttiopiskelijoiden oppiminen kestävää kehitystä edistävän kasvatuksen kehyksessä, 2009. Retrieved from http://urn.fi/URN:ISBN:978-952-10-4973-6 